\title{
A Contrastive Functional Analysis of Reference as a Cohesive Device in the English Language and Ika language
}

\author{
Professor Daniel Ogum ${ }^{1} \&$ Idegbekwe Destiny ${ }^{2}$ \\ ${ }^{1}$ Department of English and Literary Studies, University of Port Harcourt, Choba, Rivers State, Nigeria \\ ${ }^{2}$ School of Graduate Studies, Department of English and Literary Studies, University of Port Harcourt, Choba, \\ Rivers State, Nigeria \\ Correspondence: Idegbekwe Destiny, School of Graduate Studies, Department of English and Literary Studies, \\ University of Port Harcourt, Choba, Rivers State, Nigeria
}

Received: October 17, 2015

Accepted: December 2, 2016

Online Published: December 12, 2016

doi:10.5430/elr.v5n4p25

URL: http://dx.doi.org/10.5430/elr.v5n4p25

\begin{abstract}
Many definitions of language underline the fact that language is mainly a tool for communication. As a tool for communication, a language has a structure which makes it organized and understandable in relaying meanings to the users. One of such patterns of a language is found in the cohesive ties that run through the language linking what is being said to what has been said and what is to be said. This study compares reference a cohesive tie in the English language and the Ika language. The study uses the Lexical and Grammatical cohesion Model proposed by Halliday and Hassan, (1976 and Chesterman's Contrastive Functional Analysis (CFA) (1998) as the theoretical frameworks. The study establishes the similarities and differences in the functions and layout of referencing cohesive elements in the English language and Ika language. The study is done with the aim of promoting the translation of texts to and from both languages and improving the learning of English as a second language. In order to get the right data for the study, we devised the Ika English Cohesive Contrastive Template (IECCT) and applied a random sampling technique. The study presents findings and contributions to knowledge.
\end{abstract}

Keywords: Contrastive, Functional, Analysis, Translation, IECT

\section{Introduction}

One important characteristic or nature of the human language is the fact that it is structural. That is to say languages exist in different layers which combine to aid communication. Many definitions which Linguists have given in the past for language affirm the fact that language is an organized and systematic code geared toward communication. One of such definitions comes from Pyles (1964). According to him, language is a systematized combination of sounds which have meaning for all persons in a given community (p.44). Similarly, Barber (1964) says that a human language is a signaling system which uses vocal sounds as materials (p. 24). The two definitions of language above clearly highlight the fact that language exists in a systematic form.

According to Lado (1957), languages are organized layer by layer, system by system, categories by categories ranging from the phonetic, morphemic, lexical, syntactic, semantic layer to the cultural layer or system (p. 6). All the various systems of language combine to enhance the major priority of language which is communication. At this point, it is important for us to state that apart from the layers and systems identified by Lado (1957), there are other systems subsumed under a bigger layer. One of these subsumed systems of language is the system of cohesive elements that is under the semantic and lexical layer of the language. The cohesive system in a language enables the speakers to connect or tie what has been said to what is being said and what is to be said.

Cohesive systems or ties exist in most human languages. It is the duty of the linguist to study the nature and overt and covert functions of the cohesive elements in languages. The cohesive system and the resources for cohesion in the English language have been well studied and well documented in the literature. According to Halliday and Hassan (1976) there are five general ways speakers of the English language cohere their utterances. These ways include: referencing, substitution, ellipses, conjunction and lexical cohesion. These principles are used to link ideas and messages in speeches. They function in such a way that ideas and messages are linked and carried over from the previous speech situation to the present (Idegbekwe, 2014 p.1). So when people speak, the audience would understand if there is linguistic and communicative cooperation in the discourse. 
Just like every other layers in a language, the cohesive system and ties differ from one language to another. That is to say the resource(s) with which a language carries out the function of connecting utterances might be different from another language though there are points of convergence in the different languages. There are languages that are pragmatically oriented like Chinese and there are others that are grammatically oriented like English. The systems for cohesion would necessarily be different due to their orientation basis. The Chinese language uses fewer cohesive devices (cf Lu, 1979; Hu, 1993, 1994; Xu, 2002; Wang, 2005). This does not rule out the fact that both can still share similar resources for cohesion but the differences are more obvious in the two languages than the similarity.

The differences in the cohesive patterns and resources in languages bring their own challenges or problems especially in learning a second language and in translating from one language to the other. The English language today is widely spoken in the world. According to Erling (2006, p. 70 cited in Okoh 2006, p. 27) 'English has come to be commonly known as the global lingua franca. The language is noted for its international use and for the fact that non-native speakers of English outnumber native speakers three to one.' Since the English language is of high importance among language users, there would be need to learn the English language and translate the manuals in English to other languages.

One of the groups of learners of English as a second language are the Ika native language speakers. The Ika language is a language spoken by the Ika people of Delta state. It is an Igboid language spoken in Ika South and Ika North East of Delta State and also spoken in parts of Edo State. The Ika language speakers learn and speak English as a second language in order to communicate with other persons who do not speak their native language and in order to do business in the international circle. In learning the English language, they bring the rules of their first language (Ika) to the English language especially in the use of cohesive devices and other cohesive resources.

It is on this background, therefore that this study takes a look at the nature of reference which is one of the resources of cohesion in the English language vis-à-vis the Ika language. Many studies in the past focused mainly on the nature of cohesion in the English language. Also, other researchers have focused on the English language and Ika from different angles. None in the knowledge of the researcher has focused on the nature of cohesion in English and Ika, paying close attention to reference as a cohesive device. The present study is carried out in order to present the challenges the Ika speakers would face in learning English as a second language in the area of references and to aid text translation to and from the English language.

This study is aimed at unravelling the differences and similarities in the use of reference as a cohesive device between the English language and the Ika language. This study is significant because it would be of help to Ika speakers who want to learn English as a second language. To fully achieve the aim of the study, the study raised the following research questions:

1. To what extent are the referencing cohesive devices in the English language different from those in the Ika language and to what extent are the referencing cohesive devices in the English language similar to those in the Ika language?

2. In what ways would the Ika native speaker who uses English as a second language face problems or challenges in the course of using referencing devices in the English language?

\subsection{Theoretical Frameworks}

This study is anchored on two theoretical frameworks- Halliday and Hassan's (1976) Cohesion in English and Chesterman's Contrastive Functional analysis. We chose the former because the study revolves on references as cohesive devices. The latter is a framework that helps in a contrastive linguistic study like the present one. We would briefly explain both.

\subsection{Lexical and Grammatical Cohesion}

In a bid to enhance the study of the textual function of language, Halliday and Hassan (1976) identified various means which users of the English language use in connecting their text to form a meaningful whole. The devices identified by Halliday and Hassan (1976) fall into two categories: lexical and grammatical. According to Traugott and Pratt (1980, p. 21), the earliest study of cohesion in English was conducted by Jakobson (1980), who analyzed syntactic structure and parallelism in literary texts with reference to poetry.

As we stated earlier, the devices identified by Halliday and Hassan (1976) fall into two broad groups: lexical and grammatical devices. This means that some cohesion is realized through the vocabulary while some other is realized through grammar (Halliday and Hassan 1976, p.6). The elements identified by Halliday and Hassan (1976) for cohesion will form the thrust of our present study. This is because the theory of cohesion covers the nature of 
cohesion in the English language. Since we are comparing the English language and the Ika language as regards cohesion, the theory on cohesion would be very important.

Halliday and Hassan (1976) observed that the distinction between grammatical and lexical cohesion is not just a formal one where meaning is not involved in the grammatical cohesion but involved in the lexical cohesion. According to them, cohesion is a semantic system and every semantic system in the English language is realized through lexico-grammar. Another feature that makes the study of cohesion crucial is that it locates the place of cohesion in the linguistic system. Cohesion is part of the textual functional-semantic component in the linguistic system which expresses the relation between two independent clauses. Cohesion is not structurally bound unlike the ideational and interpersonal functional-semantic components which express information delivered through a clause structure that has theme and other ranking systems present in the language. Rather, cohesion can link sentences that are structurally unrelated together.

\subsection{Chesterman's Contrastive Functional Analysis}

The brand or type of contrastive methodology that we are going to use for the present study is Andrew Chesterman's meaning based model of Contrastive Analysis which he calls the Contrastive Functional Analysis (CFA). The concept of similarity lies at the heart of this brand of contrastive analysis. Similarity judgements depend partly on properties of the objects being compared, and partly on what the person considers to be relevant to the assessment; similarity, thus, has both objective and subjective aspects. Chesterman's CFA (1998) shows how contrastive analysis and translation theory make use of the concept in different ways, and explains how it relates to the problematic notions of equivalence.

One of the most prominent questions in contrastive analysis is the problem of equivalence. How do we know what to compare? It is not sufficient to contrast formal categories. What is expressed in one language by, for example, modal auxiliaries or by a high intonation could be expressed in other languages in quite different ways. We do not achieve so much by a comparison of modal auxiliaries or the pitch or intonation of the two languages in question. Instead, there should be another way of accommodating the different ways of expressing the same phenomenon in different languages which the theory seeks to provide. For example, in the present study, we are comparing the referencing cohesive devices in the English language and the Ika language. It is very possible that there might be no cohesive devices in the Ika language. There might be other ways of achieving cohesion in the Ika language but the study cannot account for them if we focus squarely on the formal devices of cohesion in the English language which has been well accounted for in many studies.

CFA can broadly be defined as a functional approach to contrastive analysis. Being functional here actually means what language is used for. According to Halliday (1985, p.xiii as cited in Chesterman 1998, p. 63) language has evolved to satisfy human needs; and the way it is organized is functional with respect to these needs. Functionalists are interested in the general relation between means and ends. That is, how a particular need is meant. Applying this to a contrastive study would imply that the way in which an expression is expressed in language A can be different in language $\mathrm{B}$ but if the end (in this case the meaning) is identical for language A and B, then, we can say they are similar and can be compared. With respect to language, it is unproblematic to define means as language form; we use certain linguistic forms (sounds, written marks, gestures and others) to achieve different communicative ends. In two different languages, the form might be different but if the end is the same, CFA is of the opinion that both languages are similar and not the same.

The operational basis of CFA is like that of the variational theory in translation teaching (Hewson and Martin, 1991). This approach is based on the idea of rewording which lies at the centre of all translation activities. What a translator needs in variation theory are options available plus the conditions matching each option. The outline starts with a set of paraphrases in the source language for a given source language sentence. This is very similar to the CFA as it seeks to establish the range of semantic options available to the two languages being compared to express a similar idea in two different cultures. CFA seeks to establish the paradigm of options with the same semantic structure.

Finally, when the distinguishing characteristics of each option have been examined in terms of their conditions for use one is selected for insertion and use. CFA filters potentials, members of the paradigm in order to select those which can be assigned the same semantic structure. CFA is a contrastive model which does not work for sameness but for similarity. That is, the way X looks like Y in language A and B. CFA argues that the similarity in language A and $\mathrm{B}$ should be treated as a hypothesis which like the null hypothesis, the analysis seeks to reject. According to Chesterman (1998, p. 198) in CFA the kinds of hypotheses that are the centre of the study or attention tend to be probalistic. The real contrativist challenge lies not in rejecting the initial identity hypothesis but in proposing a more sophisticated relativist hypothesis. 


\section{Review of Related Literature}

Linguists have always acknowledged the importantance of the internal link in language and they came up with different perspectives as to what cohesion is all about. Halliday and Hassan (1976) view cohesion as 'the principle of connectivity which binds a text together and compels co-interpretation' (p. 4). They went ahead to identify the different resources with which this inter-connectivity is achieved. Resources include: reference, substitution, and ellipsis. According to Halliday and Hassan reference, substitution, and ellipsis belong to the grammatical component

while repetition, reiteration, collocation and lexical relations belong to the lexical component. The last resource identified by Halliday and Hassan (1976) is that of conjunction.

Widdowson (1978), Carrell (1982) and Yeh (2004) counter Halliday and Hassan's (1976) position as cohesion is the only principle that connects a text or makes a text interpretable as the reader or hearer brings in his or her own knowledge (presupposition) to every language interpretation. On this conceptual difference, we stand with the opinion of Fulcher (1989) that both sides are important in studying the meaning of the language.

Many studies in the past applied the resources identified by Halliday and Hassan (1976) in analyzing different data especially the ones on written texts. Querol (2008) analysed English narratives focusing on the use of substitution. The study revealed that substitution and ellipsis have a common ground: presupposition. In substitution, presupposition is explicit. There is an explicit marker whereas in ellipsis nothing is inserted in the slot that is left open.

Shen (2008) carried out a contrastive study which was similar to the present study. However, ours differs because in Shen (2008) emphasis is placed on coherence, substitution, and reference by non-English major Chinese students paying close attention to the quality of their usages. Shen (2008) collected data through student questionnaires. Participants in the study included 30 non-English major Chinese undergraduate students. In the study, two research questions were used to investigate the quality of usages of cohesive devices. Similarly, Louwerse (2004) compared 236 language and cohesion features at the text level. Variations in frequencies across these features provided evidence for six dimensions: (1) speech versus writing (2) informational versus declarative (3) factual versus situational (4) topic consistency versus topic variation (5) elaborative versus constrained (6) narrative versus non-narrative. We must say at this point in time, that Louwerse's scope (2004) is very large compared with what we are doing at the moment, and it is not as explicit.

Many scholars, too, have applied the nature of cohesion to determine the level of recovery and understanding of sign languages and patients who have aphasia. Morgan (2000) showed that the British Sign Language makes use of cohesive devices to aid meaning value and compel co-interpretation for the users of the sign language. Morgan's study described the development of discourse cohesion in bilingual children through an analysis of narrative discourses produced by hearing children of deaf parents (HCDP) in both British Sign Language (BSL) and spoken English. Morgan (2000) findings revealed that although sign and speech require very different referential forms these children already are making appropriate shifts between languages. Thus, the simultaneous acquisition of two reference systems is not limited to languages produced and perceived in the same modality. The development of knowledge of discourse can occur across modalities within the same child.

In Nigeria, different scholars have also focused on the concept of cohesion in analyzing different types of data. Olateju (2006) focused on the low level use of cohesive ties in the written text of Nigerian secondary school students. The data used for the study were drawn from seventy final year students of Ooni Girls High School in Osun State Nigeria. Olateju (2006) discovered that though the students' work showed evidence of the use of some of the cohesive devices identified by Halliday and Hasan (1976), some of the few used were wrongly used which made it difficult for us to understand the texts. In another study, Olaniyan (2011) has shown that cohesion and coherence standards of textuality are capable of enhancing the unity and meaning of texts. Through lexical and grammatical cohesive devices, for example, text producers (writers) can generate unified, cohesive and meaningful texts that facilitate effective communication between them and texts' consumers.

Enyi and Chitulu (2015) carried out a study on the lexical cohesion in Nigeria's President Goodluck Jonathan's Inaugural Address. Guided by the theoretical postulations of Halliday's tripartite meta functions of language: the ideational, the interpersonal and the textual, with closer affinity to the textual meta function that has to do with text creation, Enyi and Chitulu (2011) presented cohesion to be a textual quality, attained through the use of grammatical and lexical elements that enable readers to perceive semantic relationships within and between sentences.

Specifically, the study concentrated on the various lexical cohesive devices the President used to bring his message and intentions to the forecourt of the listeners' and readers' attention. The basic finding was that the President made 
preponderant use of: lexical repetitions, synonyms and near synonyms, superordinate/ hyponyms and the various shades of oppositeness in language use, in fleshing out the details of his text. Lastly among the Nigerians that studied cohesion in the past, we would turn our focus to Kadiri, Otagburuagu and Ibrahim (2015). The letter studied the cohesion elements and interlanguage in the written composition of English as a second language university students in Nigeria. According to Kadiri, Otagburuagu and Ibrahim (2015, p. 76) 'Most ESL teachers in Nigeria tend to attribute the poor performance of Nigerian ESL undergraduates in the writing skill to their inability to use cohesive devices well.' In order to establish the validity or otherwise of this assumption, the study drew inspiration from this standpoint to investigate cohesion in the interlanguage of the composition texts of some Nigerian ESL undergraduates using the University of Nigeria, Nsukka as a case study. Applying the cohesion classification model of Gutwinski, (1976) the study revealed as part of its findings that the cohesion elements identified in the study as used by the learners to achieve cohesion are mainly pronoun co-ordination, subordination, substitute, and repetition. Synonym and lexical set were sparingly used by the learners.

From what we have seen above, many researchers in the past beamed their search light on many aspects of cohesion but none of these researchers focused on the analysis of the reference as a cohesive device in the English language and the Ika language which is the essence of this study.

\section{Methodology}

The research design we have adopted for this study is the descriptive design. We adopted this research design because in the study, descriptions are presented in a contrastive manner. The area of the study covers the Ika towns where the Ika language is spoken in Delta state and Edo State. The Ika language has about 240,000 speakers in Delta state (1991 census). They occupy a land area of 117.45 square kilometers the boundary between Edo and Delta State, Nigeria. Today, the Ika language is spoken not only in Ika South and Ika North East Local Government Areas of Delta State but also in villages in the Northern part of Edo state such as Igbanke, Ota and Olijie (Isichei 1976, cited in Onyeche, 2002, p.1).

\subsection{Sampling}

Using a simple random sampling technique, we selected 100 teachers in the basic schools and secondary schools that can speak and write in both the English language and the Ika language on which we administered our research instrument.

\subsection{Research Instrument}

In order to elicit the right data for the study, we developed the Ika- English Cohesive Contrastive Template (IECCT). The template works in such a way that it enables us to generate English sentences containing the resources of referencing, substitution, ellipsis, conjunction and lexical cohesion identified by Halliday and Hassan (1976) in the English language and then translate these sentences into the Ika language reflecting the cohesive items in both languages. In sentences where the resource is not available in the Ika language, the template shows the equivalent construction in the Ika language which shows a similar meaning in the English language. This is done because there are possibilities that all the resources in the English language are not available in the Ika language.

\subsection{Reliability of Instrument}

To ensure that the Ika- English Cohesive Contrastive Template (IECCT) is reliable and consistent, a pilot study involving ten teachers was carried out. The latter were instructed to translate sentences from English to Ika

\subsection{Procedure for Data Collection}

In collecting the data for this research, the researchers generated English sentences with cohesive devices and distributed them to the population of the study in order to be translated. The translated forms and their original English forms were then compared in the analysis using the Ika- English Cohesive Contrastive Template (IECCT) to check for similarities and differences in both languages.

\subsection{Method of Data Analysis}

In the analysis, each of the research questions was addressed. Then, the contrast was made between the two languages by using the sentences (both the English forms and translated forms) to see if they are similar or different. To make the contrast very explicit the Ika- English Cohesive Contrastive Template (IECCT) which we have designed highlights areas of similarities and differences in the use of cohesive devices. 


\section{Data Analysis}

1. To what extent are the referencing cohesive devices in the English language different from those in the Ika language and to what extent are the referencing cohesive devices in the English language similar to those in the Ika language?

According to Yule (2007, p. 130), 'reference can be defined as an act by which a speaker (or a writer) uses language to enable a listener (or a reader) to identify something.' References are forms or sentence constructions which refer or rely on something else either in the sentence or outside the sentence for their interpretation. There are two types of reference- the endophoric and exophoric. According to Osuafor (1999), endophoric references are forms that are retrievable within the text while the exophoric references are references that are retrievable from the context of situation, and they lie outside the text. Whichever way it comes, they are used for making a text cohesive and more interpretable. Halliday and Hassan (1975) further distinguish two types of endophoric reference. These are the anaphoric reference and the cataphoric reference. As we stated earlier, the endophoric reference expresses a semantic relation and cohesive ties forms that are retrievable within the text. 'It involves the process by which one item in a text refers to another within the same text and both items share the same referent. In other words, they are co-referentials' (Ballard, 2005, p.175).

Generally, there are two types of endophoric references in language use. They are the anaphoric and cataphoric references. The anaphoric reference occurs when the user of the language refers back to someone or something that was mentioned previously in the text. The cataphoric reference on the other hand refers to what was not mentioned before in the text but will follow immediately in the text. It is something introduced in the abstract before it is identified.

\begin{tabular}{|c|c|c|c|c|c|c|}
\hline S/no & $\begin{array}{l}\text { English } \\
\text { Sentence }\end{array}$ & $\begin{array}{l}\text { Cohesive } \\
\text { Type }\end{array}$ & $\begin{array}{l}\text { Cohesive } \\
\text { Items }\end{array}$ & $\begin{array}{l}\text { Translated } \\
\text { Ika Sentence }\end{array}$ & $\begin{array}{l}\text { Cohesive } \\
\text { Type }\end{array}$ & $\begin{array}{l}\text { Cohesive } \\
\text { Items }\end{array}$ \\
\hline 1 & $\begin{array}{l}\text { I met my } \\
\text { friend } \\
\text { yesterday }\end{array}$ & $\begin{array}{l}\text { Cataphoric } \\
\text { Reference }\end{array}$ & $\begin{array}{l}\text { My friend, } \\
\text { John }\end{array}$ & $\begin{array}{l}\text { M kurun o wim } \\
\text { Johni oya ahun }\end{array}$ & $\begin{array}{l}\text { Cataphoric } \\
\text { Reference }\end{array}$ & Owim, Johni \\
\hline 2 & $\begin{array}{l}\text { I salute you, } \\
\text { my in-laws }\end{array}$ & $\begin{array}{l}\text { Cataphoric } \\
\text { Reference }\end{array}$ & You, in-laws & $\begin{array}{l}\text { Eke lem onu } \\
\text { ndi ogom }\end{array}$ & $\begin{array}{l}\text { Cataphoric } \\
\text { Reference }\end{array}$ & Onu, ndi ogom \\
\hline 3 & $\begin{array}{l}\text { Emeka } \\
\text { brought my } \\
\text { properties; } \\
\text { books, and } \\
\text { cars back }\end{array}$ & $\begin{array}{l}\text { Cataphoric } \\
\text { Reference }\end{array}$ & $\begin{array}{l}\text { Properties, } \\
\text { books and } \\
\text { cars }\end{array}$ & $\begin{array}{l}\text { Emeka we he } \\
\text { akum; } \\
\text { ehwuwor } \\
\text { moto }\end{array}$ & $\begin{array}{l}\text { Cataphoric } \\
\text { reference }\end{array}$ & $\begin{array}{l}\text { Akum, } \\
\text { ehwuwor } \\
\text { moto }\end{array}$ \\
\hline 4 & $\begin{array}{l}\text { It is finished. } \\
\text { My problems, } \\
\text { sorrows and } \\
\text { pains are all } \\
\text { gone }\end{array}$ & $\begin{array}{l}\text { Cataphoric } \\
\text { Reference }\end{array}$ & $\begin{array}{l}\text { Finished, My } \\
\text { problems, } \\
\text { sorrows and } \\
\text { pains }\end{array}$ & $\begin{array}{l}\text { Nsogbu m, } \\
\text { ariron le ekwa } \\
\text { m agwu gwo. }\end{array}$ & None & None \\
\hline 5 & $\begin{array}{l}\text { I would } \\
\text { never have } \\
\text { believed it. } \\
\text { They } \\
\text { accepted. }\end{array}$ & $\begin{array}{l}\text { Cataphoric } \\
\text { reference }\end{array}$ & $\begin{array}{l}\text { It, they } \\
\text { accepted }\end{array}$ & $\begin{array}{l}\text { O we ni kem ke } \\
\text { gi kweri ni } \\
\text { oweri we }\end{array}$ & None & None \\
\hline 6 & $\begin{array}{l}\text { I saw } \underline{\text { a girl }} \\
\text { named } \underline{\text { Joan }}\end{array}$ & $\begin{array}{l}\text { Cataphoric } \\
\text { reference }\end{array}$ & a girl, Joan & $\begin{array}{l}\text { M hun okpoho } \\
\text { ohu e fan wu } \\
\underline{\text { Joan }}\end{array}$ & $\begin{array}{l}\text { Cataphoric } \\
\text { reference }\end{array}$ & $\begin{array}{l}\text { okpoho } \\
\text { Joan }\end{array}$ \\
\hline 7 & $\begin{array}{l}\text { I saw the girl } \\
\text { named } \underline{\text { Joan }}\end{array}$ & $\begin{array}{l}\text { Cataphoric } \\
\text { reference }\end{array}$ & $\begin{array}{l}\text { The } \\
\text { Joan }\end{array}$ & $\begin{array}{l}\text { M hun okpoho } \\
\underline{\text { ahun e fan wu }} \\
\underline{\text { Joan }}\end{array}$ & $\begin{array}{l}\text { Cataphoric } \\
\text { reference }\end{array}$ & $\begin{array}{l}\text { okpoho } \\
\text { Joan }\end{array}$ \\
\hline
\end{tabular}

At this point in time, we would now present the analysis of the Ika and English sentences to see to what extent they are different in use. 


\subsection{Cataphoric Reference}

In the English language and the Ika language, the cataphoric reference revolves around the use of a word, in most cases noun phrases, to refer to another word that comes later in the text where the word that comes later illuminates the first or explains the first better. Let us consider some sentences from the two languages using the IECCT to present the data for proper explication of the device of cataphoric reference in the two languages:

\section{(IECCT display of the cataphoric use in the Ika and English sentences)}

In sentences 1, 2 and 3 above the use of cataphoric referencing in both languages is very similar because both languages permit the use of such items within a clause structure. That is, two noun phrases (henceforth referred to as NP) are referencing each other within a clause. In sentence 1, the NP my friend/owi $m$ cataphorically refers to another NP John in which case, John as the second NP clarifies the first NP in the same clause. The same thing happens in sentences 2 and 3 where in sentence 2 the NP you/onu refers cataphorically to another NP my in-laws/ndi ogom and in sentence 3, the NP my properties/akum cataphorically refers to another NP books and cars/ehwuwor le moto. What makes the three sentences similar in the English language and the Ika language is that they operate within the same clause. So, one can say that the cataphoric reference is possible in the two languages if the referents within the same clause.

However, they are similar in this form, there is a difference in the layout of the NPs in both languages. The English language can take pre-modification of the head of the NP such as my friend and also take post modification such as a friend of mine. The Ika language can only take the post modification form; where the possessive noun that comes before the head in the English NP comes after the head. Thus, in the Ika language, the possessive pronoun $m$ (my) comes after the head of the NP owi (friend) and used as owi $m$ but in the English language it is the other way round (my friend). Subsequently, we would focus on the likely problems a difference in phrasal and clausal structure might bring to Ika language speakers who would wish to learn the English language.

As we have seen above, the NPs can refer cataphorically in both languages if they are within the same clause. But NPs in the English language can be referred to cataphorically between two clauses especially if the referencing items are clauses. The Ika language does not have the same principle. In sentence 4 the clause it is finished cataphorically refers to my problems, pains and sorrow are gone; where the second clause illuminates the first. In this case, the second clause tells us what is finished, and one can also interpret it as the problems, pain and sorrows together got finished. So, they are co-referentials in the English language. In the Ika language such a construction or reference is not possible as it would sound awkward and the meaning lost as there are no two words for finished and gone in the Ika language. The Ika word $a$ gwu gwo would function in both clauses to read as: $O$ gwu gwo. Nsogbum, ariron le ekwa agwu gwo which is a possible statement but very much restricted in use as it is usually not the norm expression in the Ika language. In a sentence like the one above in the Ika language, the cohesive item is not a cataphoric reference. Instead, it would be repetition which sounds unnecessary in this instance of use.

In fact, both clauses would be expressed together to read as: Nsogbu $m$, ariron le ekwa $m$ agwu gwo which literally means my problems, pain and sorrows are over. In this case, there is no cataphoric cohesive item as revealed in the IECCT. The same thing applies to sentence 5 where in the English language a clause can refer to another (cataphors). However, this is not possible in the Ika language. In sentence 5, the first clause: I would never have believed it, refers forward to another clause they accepted. This type of across clausal cataphoric reference is not possible in the Ika language as again the sentence would sound awkward and the meaning lost. Instead in the Ika language, it would be expressed in the same sentence such as: $O$ we ni kem ke gi kweri ni oweri we and there would be no obvious cohesive element though it would be interpretable.

Lastly, concerning the nature of cataphoric referencing device in the English language and the Ika language, we would focus on the internal structures of the NP in both languages. Cataphoric references according to Halliday and Hassan (1976 operate at the NP level of languages, and in a systematic way helps in relating the NPs in a text. There are different types of NPs in languages including:

Proper names: John, Mark, Abuja (English); Chukwuma, Emeka, Ebere (Ika)

Pronouns: he, they she (English); m, o, enyi (Ika)

Possessives: my book, our food, his bag (English); ewhuwhor m, ihieri m, ekpa a (Ika)

Demonstrative descriptions: this girl, that girl, these girls (English); okpoho ni, okpoho ahun, ikpoho ni (Ika)

Quantificational description: two girls, three girls (English); ikpoho ebwo, ikpoho eto (Ika)

Definite description: the book, the man (English); * ewhuwhor ohu, *okeye ohu (Ika) 
Indefinite description: a book, a man (English); * ewhuwhor ohu, *okeye ohu (Ika)

Bare NP: men, women (English); ikeyen, ikpoho (Ika)

All the NPs stated above are possible in the English language, and they can be used for cataphoric referencing. In the Ika language all the NPs are possible except the definite description NP and the indefinite description NP. This is because the Ika language does not make use of articles like the English language. A possible way of saying an NP with articles in the Ika language is by adding numbers which changes the structure to the quantificational description of an NP.

At this point in time, let us use sentences in the IECCT to illustrate this fact. In sentences 6 and 7 in the template the two languages cohere cataphorically in different ways but the meaning is not lost on both occasions. In sentence 6: $I$ saw a girl named Joan/M hun okpoho ohu e fan wu Joan, the idea in the English sentence is the same with that of the Ika equivalent. okpoho ohu literally means one girl, where one is substituted for the indefinite article $a$; because the Ika language lacks the articles.

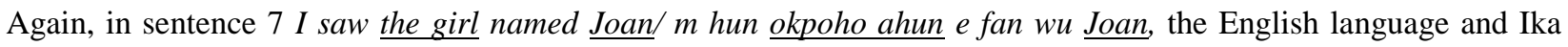
language make use of different resources to achieve cataphoric reference. In this case, the Ika language uses ahun (that) to account for the definite article the in the English equivalent. In terms of meaning, the two languages achieve the idea of a specific reference (the) and that of pointing which is demonstratives (that) do. By using the indefinite article $a$ in sentence 6, the English language means the girl is not known to the speaker and listener and by using the definite article the in sentence 7 the English sentence means the girl is known to the speaker and listener. The same thing applies in the Ika language: using ohu (one) for the girl makes the referent indefinite, not known to the speaker and listener. Then, using ahun (that) for the girl in sentence 7 shows definiteness though different from the English language which uses that for pointing purposes. The difference in the use of ahun (that) in the Ika language as a definite reference and its use as a pointing item (demonstrative pronoun) are pragmatically understood by the speakers of the language. The Ika language makes use of the situation and environment (pragmatically oriented) much more than the English language which relies more on grammar (grammatically oriented).

If the meanings in the Ika language and the English language as expressed in sentence 6 and 7 are similar, then functionally, both languages are similar because they achieve the same aim as Chesterman (1998) outlined. According to him, what a functional contrastive should do is to focus on similarity in meaning rather than sameness in meaning which is very rare in two languages. For Ika language speakers who intend to learn the English language, and vice versa, this structural difference would indeed create problems for the learners which we would examine later.

In all, from the analysis of cataphoric cohesive devices in the English language and the Ika language, we can conclude that cataphoric referencing devices are present in the two languages but in different comportments and layouts. While both languages permit the use of NP to cataphorically refer to another NP in the same clause, the Ika language does not allow the use of clauses to cataphorically refer to another clause which is possible in the English language. Also, we have seen that there is a difference in the structure of the NP which is the main vehicle for cataphoric referencing in both languages.

\subsection{Anaphoric Reference}

Anaphoric references refer backwards in a text for interpretation and meaning. The major devices used for anaphoric references are the pronominal anaphors such as we, he, it, she, her, me, my, our, their, you etc (Osuafor, 103). In other words 'anaphora can be defined as a subsequent reference to an already introduced entity': (Yule, 2007, p.131). In the Ika language and the English language, the anaphora reference exists. We would now use the IECCT to present sentences in both languages to demonstrate the differences and similarities. 


\begin{tabular}{|c|c|c|c|c|c|c|}
\hline S/no & English Sentence & $\begin{array}{l}\text { Cohesive } \\
\text { Type }\end{array}$ & $\begin{array}{l}\text { Cohesive } \\
\text { Items }\end{array}$ & $\begin{array}{l}\text { Translated Ika } \\
\text { Sentence }\end{array}$ & $\begin{array}{l}\text { Cohesive } \\
\text { Type }\end{array}$ & Cohesive Item \\
\hline 8 & $\begin{array}{l}\text { They met two persons } \\
\text { at home: a male and a } \\
\text { female. The male is } \\
\text { their father's friend } \\
\text { and he loves them so } \\
\text { much. The female is a } \\
\text { teacher in one of the } \\
\text { schools in the town } \\
\text { and she sells books } \\
\text { too. He hugged them } \\
\text { and she smiled. }\end{array}$ & $\begin{array}{l}\text { Anaphoric } \\
\text { reference }\end{array}$ & $\begin{array}{l}\text { He } \\
\text { (Marking } \\
\text { Gender) } \\
\text { She } \\
\text { (Marking } \\
\text { Gender) }\end{array}$ & 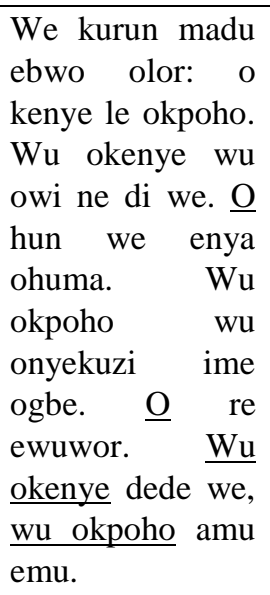 & $\begin{array}{l}\text { Anaphoric } \\
\text { reference }\end{array}$ & $\begin{array}{l}\text { O (Not } \\
\text { marking } \\
\text { Gender) } \\
\text { Okenye, } \\
\text { Okpoho } \\
\text { (lexical Items } \\
\text { Needed for } \\
\text { explicitness }\end{array}$ \\
\hline 9 & $\begin{array}{l}\text { I met John yesterday. } \\
\text { He was looking very } \\
\text { happy and I told him } \\
\text { about Mary who he } \\
\text { had seen on two } \\
\text { occasions before. I } \\
\text { believe they would be } \\
\text { good friends } \\
\text { especially when she } \\
\text { wants the friendship. }\end{array}$ & $\begin{array}{l}\text { Anaphoric } \\
\text { reference }\end{array}$ & $\begin{array}{l}\text { He, him } \\
\text { she } \\
\text { (marking } \\
\text { gender) } \\
\text { They }\end{array}$ & $\begin{array}{l}\text { M kurun } \underline{\text { John }} \\
\text { oyaahun. } \underline{\mathrm{O}} \text { le ke } \\
\text { onye efo swo } \\
\text { ohuma mno gwa } \\
\underline{\text { a ni ahum Mary }} \\
\text { wu o onwo gwo } \\
\text { mgbe ebwo. M } \\
\text { kweri ni we ka } \\
\text { wu ezigbo oyi } \\
\text { ebo me ni ori a } \\
\text { swo wu okpoho. }\end{array}$ & $\begin{array}{l}\text { Anaphoric } \\
\text { reference }\end{array}$ & $\begin{array}{l}\text { O, a, we, (not } \\
\text { marking } \\
\text { gender) } \\
\text { Wu okenye, } \\
\text { wu okpoho }\end{array}$ \\
\hline 10 & $\begin{array}{l}\text { I saw the table this } \\
\text { morning. } \underline{\text { It }} \text { was } \\
\text { shining and I touched } \\
\text { it. }\end{array}$ & $\begin{array}{l}\text { Anaphoric } \\
\text { reference }\end{array}$ & It & $\begin{array}{l}\text { A hum agara } \\
\text { ahun ozotutun ni. } \\
\text { O wu eh be wam } \\
\text { wam n nor je eka } \\
\text { gi de } \underline{\mathrm{e}}\end{array}$ & $\begin{array}{l}\text { Anaphoric } \\
\text { reference }\end{array}$ & $\mathrm{O}, \mathrm{e}$ \\
\hline 11 & $\begin{array}{l}\text { Emeka, Isioma and } \\
\text { Ayo came for the } \\
\text { meeting. They were } \\
\text { punctual too. }\end{array}$ & $\begin{array}{l}\text { Anaphoric } \\
\text { reference }\end{array}$ & They & $\begin{array}{l}\text { Emeka, Isioma le } \\
\text { Ayo bia nzo me } \\
\text { enyi. We bia } \\
\text { gwa. }\end{array}$ & $\begin{array}{l}\text { Anaphoric } \\
\text { reference }\end{array}$ & $\mathrm{We}$ \\
\hline
\end{tabular}

\section{(IECCT display of the use of Anaphoric Reference in both Languages)}

A look at the template above reveals that the English language and the Ika language make use of anaphoric referencing but with so much difference in the components and layout of pronouns. While the English language makes a clear distinction in gender (masculine, feminine and neuter) using he, him, she, her and it, the Ika language makes use of $o$ for all the genders. The two languages have the plural third person pronoun as used in the template above where they is for the English language while we is for the Ika language. To fully understand the difference in the pronoun layout in both languages, we would present a table showing the personal pronouns. The first table shows the personal pronouns in the English language while the second table shows the personal pronouns in the Ika language. 


\begin{tabular}{lllll}
\hline & Singular subject & Plural subject & Singular object & Plural object \\
\hline First person & I & We & Me & Us \\
Second person & You & You & You & You \\
Third person & He (masculine) & They & Him (masculine) & Them \\
& She (feminine) & (all genders) & Her (feminine) & (all genders) \\
& It (neuter) & & It (neuter) & \\
\hline
\end{tabular}

(Personal pronouns in the English language and their nature)

\begin{tabular}{lllll}
\hline & Singular subject & Plural subject & Singular object & Plural object \\
\hline First person & $\mathrm{a}, \quad \mathrm{me}$ & Enyi & $\mathrm{M}$ & Enyi \\
Second person & $\mathrm{Yu}$ & $\mathrm{Onu}$ & $\mathrm{Ye}$ & Onu \\
Third person & ya, o & We & $\mathrm{Ye}$ & we \\
& (all genders) & (all genders) & (all genders) & (all genders) \\
& & & (neuter) & \\
\hline
\end{tabular}

(Personal pronouns in the Ika language and their nature)

Though there is no gender distinction in the Ika language, this does not prevent the language from being able to cohere anaphorically as the language employs different mechanisms which we would be looking at. This point is well documented by Westermann and Bryan in their 1970 study of West Africa languages. They posit that Kwa language family which the Igbo language and by extension the Ika language is part of does not mark or has grammatical gender but there are different means of avoiding confusion and ambiguity (p. 92). The Ika language makes use of explicit items especially nouns that show gender distinctions in a text where the general $o$ pronoun which does not mark gender should have been used. Also, the language makes use of the context to delineate meanings and avoid ambiguity. The obvious difference from the tables above is in the area of gender marking. The use of pronouns which mark gender in the English language enhances the internal link in a text and helps the English users to tie, relate and refer items clearly without ambiguities in reference. In the Ika language, the pronouns do not mark gender but lexical items are introduced as meaning cushioning which helps to disambiguate the reference of the non-gender sensitive $o$.

In sentence 8 in the template, the English sentence makes use of he and she to refer backwards to the two persons who met in the room-the man and the woman - and there is a clear distinction in the reference, subsequently. In the Ika language, the pronoun $o$ is used only when the lexical item okenye and okpoho have been used to show which of the genders $o$ is being referred to. This is a clear difference in the two languages though they end up achieving a similar meaning. When making referents backward for plural third persons, the Ika language and the English language do not mark gender in plurality. While the English language uses they (subject) and them (object), the Ika language makes use of we (subject) and we (object). The English language changes the pronoun from they to them but the Ika language keeps we both in subject and object position. The Ika language speakers know when we is performing as action and when it is receiving actions. But they might not be aware that the position of the plural we determines the grammatical function in the pronoun usage. If we comes first in the clause, it is subject and when it comes last in the clause, it is receiving action.

In sentence 9, the differences in gender marking in the two languages also show up as the English sentence uses he and she while the Ika language uses wu okenye and wu okpoho. It would be uncomfortable to really categorize the nature of the anaphoric reference in the Ika language especially in gender marking as reference or as anaphoric reference in the true sense of the term. Anaphoric references use pronouns mainly to refer backward. When it is something else, (the same noun) it is sketchy to call it anaphora. The use of the same lexical item twice or more in a text belongs to another type of cohesive devices which is known as lexical cohesion. So, we can conclude that due to the lack of gender marking in the Ika language, the cohesive pattern of anaphora is difficult to sustain when gender is involved. Instead, the Ika language uses the resources of lexical cohesion which we would focus on later in the study.

At this point in time in the study of the anaphora system in the English language and the Ika language, we would focus on the use of neuter gender in the two languages. In sentence 10, there is a marked difference in the use of the neuter gender in both languages. While the English language makes use of it (Subject) and it (object), the Ika 
language makes use of $o$ (subject) and $e$ (object). A clear demonstration of this is in sentence 10 is displayed the IECCT above. While the English language repeats $i t$ in the object form as it has been used in the subject, the Ika language uses $e$ for the object position. Just as the Ika speakers interpret we as both subject and object, the English speakers also interpret it as subject and object depending on clausal positioning and what is performing the action or receiving the action at any point in time.

What is noticeable from the analysis so far is the characteristic nature of the third person pronoun forms to always function anaphorically. If a proper noun like Emeka is used at the beginning of a text, the third person pronoun he, him or continues to refer to Emeka.

In the English language and the Ika language, the elements of anaphora in texts are present but as we have seen above in the analysis, there are differences and similarities which mainly arise in the nature of pronouns in the two languages.

\subsection{Exophoric Reference}

An exophoric reference alludes to events that are outside the text. That is to say, its reference is not interpretable from the text rather it is in the context of situation. This type of reference depends on the speech context or an event outside the speech context for interpretation. Without the context, stated above, the interpretation of what is said is impossible. It is expedient to note that while cataphoric and anaphoric referencing refers to items in the text for interpretations, the exophoric reference is not in the text. According to Halliday and Hassan (1976, p. 33), "an exophoric item, however, is one which does not name anything; it signals that reference must be made to the context of situation." In the real sense of reference, the first person and the second person pronoun forms do not refer to the text in most cases for interpretation. This is because their referents are defined by the speech roles of the speaker and the hearer and hence they are normally interpreted exophorically, by reference to the situation (Halliday \& Hassan, 1975, p. 48). This assertion above is not in any way refuting the fact that other items can function exophorically but establishes the fact that this group of pronouns forms the bulk of the exophoric reference.

The Ika language and the English language use the exophoric reference to link or connect what is being said to the speech situation and things/concepts outside the speech situation. To fully illustrate this fact, we would also use the IECCT to present sentences in the English language and their translations in the Ika language.

\begin{tabular}{|c|c|c|c|c|c|c|}
\hline S/no & English Sentence & $\begin{array}{l}\text { Cohesive } \\
\text { Type }\end{array}$ & $\begin{array}{l}\text { Cohesive } \\
\text { Items }\end{array}$ & $\begin{array}{l}\text { Translated Ika } \\
\text { Sentence }\end{array}$ & $\begin{array}{l}\text { Cohesive } \\
\text { Type }\end{array}$ & Cohesive Item \\
\hline 12 & $\begin{array}{l}\text { We are here because } \\
\text { of you. You made the } \\
\text { event possible and I } \\
\text { would do my best for } \\
\text { you. }\end{array}$ & $\begin{array}{l}\text { Exophoric } \\
\text { reference }\end{array}$ & $\begin{array}{l}\text { We, you, I, } \\
\text { here, the } \\
\text { event }\end{array}$ & $\begin{array}{l}\text { Enyi ri ebe ni } \\
\text { meke yu. Yu me } \\
\text { mgbako ni gha. } \\
\text { M ke me ni wu } \\
\text { ka chanma }\end{array}$ & $\begin{array}{l}\text { Exophoric } \\
\text { reference }\end{array}$ & $\begin{array}{ll}\begin{array}{l}\text { Enyi, yu, m, } \\
\text { ebe }\end{array} & \text { ni, } \\
\text { mgbako } & \end{array}$ \\
\hline 13 & $\begin{array}{l}\text { This car is dirty and } \\
\text { that car is neat }\end{array}$ & $\begin{array}{l}\text { Exophoric } \\
\text { reference }\end{array}$ & This, that & $\begin{array}{l}\text { Moto ni run uhie. } \\
\text { Moto ahun wun } \\
\text { ewun }\end{array}$ & $\begin{array}{l}\text { Exophoric } \\
\text { reference }\end{array}$ & $\mathrm{Ni}$, ahun \\
\hline 14 & $\begin{array}{l}\text { I am talking to you to } \\
\text { desist from these evil } \\
\text { ways as it would not } \\
\text { help us in any way. } \\
\text { We are to perform } \\
\text { our duty in a } \\
\text { respectable manner }\end{array}$ & $\begin{array}{l}\text { Exophoric } \\
\text { reference }\end{array}$ & $\begin{array}{l}\text { I, you, these } \\
\text { evil ways, } \\
\text { us we, our }\end{array}$ & $\begin{array}{l}\text { M ra gwa onu ni } \\
\text { no onu gba ni } \\
\text { ejihien ndi ni le } \\
\text { oso no yeke eyi } \\
\text { eka. Enyi ka run } \\
\text { orun enyi ohuma } \\
\text { ohuma }\end{array}$ & $\begin{array}{l}\text { Exophoric } \\
\text { reference }\end{array}$ & $\begin{array}{l}\text { M, onu, enyi } \\
\text { ejihien ndi ni } \\
\text { le }\end{array}$ \\
\hline 15 & $\begin{array}{l}\text { Today, we would rise } \\
\text { up and support our } \\
\text { leaders. Yesterday is } \\
\text { gone, tomorrow is } \\
\text { another day. }\end{array}$ & $\begin{array}{l}\text { Exophoric } \\
\text { reference }\end{array}$ & $\begin{array}{l}\text { Today, we, } \\
\text { our, } \\
\text { yesterday, } \\
\text { tomorrow }\end{array}$ & $\begin{array}{l}\text { Tani, enyi ke } \\
\text { lihie ye ni ndi ra } \\
\text { ki enyi eka. Oya } \\
\text { ahun agwu gwo, } \\
\text { eki wu owehie } \\
\text { ichien. }\end{array}$ & $\begin{array}{l}\text { Exophoric } \\
\text { reference }\end{array}$ & $\begin{array}{l}\text { Tani, enyi, oya } \\
\text { hun, eki }\end{array}$ \\
\hline
\end{tabular}

(IECCT a display of the use of Exophoric Reference in both Languages) 
A look at the items identified above as showing exophoric references in the template reveals that the information they carry is really not in the text, rather, it is in the situation or speech context. In sentence 12 , the pronoun we/enyi, $I / m$, you/yu all have their referents outside the text. They can only be interpreted as $I / m$ the speaker and that point in time; welenyi, the speaker talking on behalf of others; you/yu, the addressee. For proper interpretation, one needs to know the important actors in the speech situation which the pronouns are referencing to. The English language pronoun system is structured in such a way that the second person pronoun form is not well specified in terms of number. That is, it is difficult to determine whether the pronoun you is referring to singular or plural at any point in time as there is nothing in the grammar that suggests that. In the Ika language, there is a marked difference which in a way aids cohesion though not fully without the context. The Ika language uses yu/ye for the singular addressee then on $u$ for the plural addressee. In the English language, it is you and you for both singular and plural.

Following the difference above, the Ika language sentence containing second person pronoun is likely to be interpretable at least in number. Let us look at the following sentences to demonstrate this fact:

English: I am talking to you (can be singular or plural)

Ika: $M$ ra gwa yu (singular reference)

Ika: $M$ ra gwa onu (plural reference)

While the English language reference interpretation for you would seek the context of speech or speech situation to interpret the sentence fully (number and name), the Ika language sentence would seek the speech context to interpret only the name and not number because it is part of the grammar.

Sentence 13 highlights the presence of demonstrative pronouns in both languages. While the English languages uses: this, that, these and those; the Ika language makes use of $n i$ and ahun. The Ika language marks a spatial distinction in terms of how close the object is to the speaker and listeners just like the English language using this/ni for a close object, and that/ahun for a far object. The Ika language does not have the plural forms for demonstrative pronouns (these and those in the English language). Instead, the object alone is pluralized whereas in the English language demonstrative pronouns are pluralized.

As we saw in the earlier analysis, the English language can pre-modify the head of a noun phrase in: that car; in the Ika language, it is post modified in moto ni. In terms of text translation from English to Ika, these differences would create difficulties in gloss translation. Also, these differences would certainly bring their own type of learners' errors which we would focus on later. The overriding idea here is that demonstrative pronouns are interpreted from the speech situation in both languages.

Sentence 14 introduces another pronoun us/enyi and our/nke enyi that function exophorically. The major difference here lies in the repetition of enyi for we and enyi for us. The difference in the first and second enyi is in the position of the clause. If it comes first, it is the subject and if it comes last in the clause, it is object. Their references and interpretation lie outside the text. They are in the speech context. If we say they are in the speech context, we mean the referents are not stated in the text but can be decoded from those present. According to Halliday and Hassan (1976, p. 54) any user of the language understands this situation because at any point in time, the user of the language performs any of the speech function of either speaker/writer or listener/reader. All the people referred to must not be present before establishing them as members of the reference with we. The speaker can be the leader of the group whose members are not actually present in the immediate context of the speech. Also, Halliday and Hassan (1976) are of the opinion that when we say exophoric references are context depended, it does not mean that the referents must be physically present during the speech; it merely means that the context or situation permits the identification of the referent to be made.

What we have done so far in this session on analysis is to look at the areas of similarities and differences inherent in the referencing cohesive devices in the two languages under focus- English and Ika. We have seen that though both languages share referencing items, manner and layouts of these items differ in both languages. We would now shift our attention to other cohesive devices identified by Halliday and Hassan (1976) to examine the similarities and differences in both languages.

2. In what ways would the Ika native speaker who speaks or is learning English as a second language face problems or challenges in the course of learning/using cohesion in the English language?

In this section, we would now set out to answer the second question which we established earlier in the course of the research. In this section, we would look back on those similarities and differences and predict the likely where the 
Ika language speakers who intend to learn and use the English language would likely face problems. This would be of help to language teachers and also to text translators to and from both languages.

In the use of references, Ika language speakers would probably face problems with the English language with the use of definite and indefinite references, demonstratives and gender. For the different types of NP available in the English language as we saw arlier, the Ika language does not have the definite reference NP. The indefinite reference NP and the demonstrative system in the Ika language do not accommodate plurals. For proper understanding, we present the various Nps again as we did earlier:

Proper names: John, Mark, Abuja (English); Chukwuma, Emeka, Ebere (Ika)

Pronouns: he, they she (English); m, o, enyi (Ika)

Possessives: my book, our food, his bag (English); ewhuwhor m, ihieri m, ekpa a (Ika)

Demonstrative descriptions: this girl, that girl, these girls (English); okpoho ni, okpoho ahun, ikpoho ni (Ika)

Quantificational description: two girls, three girls (English); ikpoho ebwo, ikpoho eto (Ika)

Definite description: the book, the man (English); * ewhuwhor ohu, *okeye ohu (Ika)

Indefinite description: a book, a man (English); * ewhuwhor ohu, *okeye ohu (Ika)

Bare NP: men, women (English); ikeyen, ikpoho (Ika)

There is no article in the Ika language, and as such, English expressions with articles need to be converted with a demonstrative pronoun and in terms of the functional level of the Ika form, we wish to state that it fulfils the relatedness in meaning as outlined by Chesterman (1998). That is to say the communicative value of:

\section{The man is here}

A man is here is more less the same with the Ika version of

$$
\begin{array}{ll}
\text { Okenye ahun bia ebeni } & \text { (that man came here) } \\
\text { Okenye ohu bia ebeni } & \text { (one man came here) }
\end{array}
$$

In the case of using ahun (that) for the and ohu (one) for a by the Ika language, the Ika speakers understand the first as a definite reference as the speaker and the listeners are aware of the existence of such a man, and in the second case, the use of ahun (one) points to the fact that they (speakers and listeners) are not aware of such an individual. So, it is related to the English meaning and satisfies the condition for contrasting as proposed by Chesterman (1998).

However, this difference in system of achieving related meaning in reference breeds its own problems for the second language learner which is evident from the type of sentences they generate. One would be surprised if there is a negative transfer from the Ika language to the English language. This would result in sentences such as:

\section{That man came, for the man came here and \\ One man came here, for a man came here}

If the learners continue to substitute that for the and one for $a$ in order to align with the system of the Ika language which is their first language, their ability to communicate in the English language is highly hampered and can create the wrong intentions in a speech situation. Since this difference exists, it is advisable for teachers of English as a second language to be aware of this fact while they teach in the Ika area and by extension other Kwa languages (though more researches are needed to determine the extent to which this applies to other Kwa languages). This would help them to concentrate on materials aimed at solving these learners' problems.

On the use of demonstratives, we wish to state that the English language has four demonstrative pronouns: this that (singular), these those (plural) while the Ika language has just two huni (this) ahun (that). In the Ika language, the plural demonstratives are not used instead, the noun is pluralized. There is a likelihood of Ika speakers shunning the plural demonstrative in the English language and generating sentences that tally with the system of the Ika language. Possible sentences that can emanate are as follows:

\section{That boys came here}

This girls are not happy

The examples above are cases where the nouns are pluralized while the articles remain singular. This is not the system of the English language but that of the Ika language, and from the difference existing, there can be negative concerns for learners of the English language. 
Another area of problem in the use of reference for the Ika language speakers who intend or are earning the English language is the lack of gender distinction in the Ika language pronoun system. The English language marks gender especially in the third person usage but this is not the same with the Ika language. The Ika language makes use of explicit items especially nouns that show gender distinctions in a text where the general $o$ pronoun which does not mark gender should have been used. Also, the language makes use of the context to delineate meanings and avoid ambiguity. The obvious difference from the table for personal pronouns is in the area of gender marking. The use of pronouns which mark gender in the English language enhances the internal link in a text and helps the English users to tie, relate and refer items clearly without ambiguities in reference. In the Ika language, the pronouns do not mark gender but lexical items are introduced as meaning cushioning which help to disambiguate the reference of the non-gender sensitive $o$. In both languages, ambiguities are avoided in different ways. But the Ika speaker would have to cope with this while learning the English language as there might be confusion in the use of her, she, he, him and it as they are all gender sensitive.

Related to gender marking in both languages is the presence of a difference in the second person usage. While the Ika language does not differentiate singular and plural second person, (you) the Ika language does. The Ika language uses $y u$ (singular) and onu (plural). This leads to the problem of assumption where the Ika native speaker would make the mistake of assuming that it is the same with the English language. Where the pronoun you is assumed wrongly to be singular while you people is the plural form.

\section{Findings}

A functional contrastive analysis of the referencing cohesive device in the English language and the Ika language reveals that:

1. The use of cataphoric reference in the English language and the Ika language are only similar if the referencing items are in the same clause. While the Ika language can only make cataphoric reference within the clause, the English language can make cataphoric reference within and outside clause boundaries. This is well exemplified by sentences $1,2,3$ and 4 . We would take sentence 1 and 4 to illustrate this finding. $I$ met my friend John yesterday/M kurun o wim Johni oya ahun in the instance above, John/Joni and my friend/owim are in the same clause my friend/owim and refer cataphorically to John/Joni. This is possible in both languages because they are in the same clause. But sentence 4 below: It is finished. My problems, sorrows and pains are all gonel Nsogbu m, ariron le ekwa m agwu gwo shows that if the referencing items are in different clauses, the English language can still refer cataphorically but the IKa language cannot.

2. The Ika language can only take post modification of the head of the Noun Phrase unlike the English language that can take the pre-modification and post modification. The English language can take pre-modification of the head of the NP such as my friend and also can take post modification such as a friend of mine. The Ika language can only take the post modification form; where the possessive noun that comes before the head in the English NP is taken. So, the English language can have the head of the Noun phrase at the initial and final position while the Ika language has it at the initial position only.

3. There is no article in the Ika language and as such there is no definite description and indefinite description noun phrase. A possible way of saying an NP with articles in the Ika language is by adding numbers. This changes the structure to the quantificational description NP. In sentence 6: I saw a girl named Joan/ M hun okpoho ohu e fan wu Joan, the idea in the English sentence is the same with that of the Ika equivalent. okpoho ohu literarily means one girl. Where one is substituted for the indefinite article $a$; because the Ika language lacks the articles. Again, in sentence 7 I saw the girl named Joan/ $m$ hun okpoho ahun e fan wu Joan, the English language and Ika language make use of different resources to achieve cataphoric reference. In this case, the Ika language uses ahun (that) to account for the definite article the in the English equivalent.

4. In pronoun usage, there is no gender distinction in the Ika language as it is in the English language. We discovered this by designing a table for the personal pronouns in both languages. The English language can distinguish masculine, feminine and neuter genders but the Ika language does not mark gender at all. The Ika language uses lexical items and the context of situation to avoid ambiguities in expressions.

\section{Conclusion}

In concluding this research, we wish to state that our main focus in this research has been to $\mathrm{x}$-tray the nature of cohesive devices in the English language and the Ika language in order to provide enough description for both of 
them for the benefit of English as a second language teacher who would teach students who speak the Ika language as their native language. This study used the IECC template to generate sentences that have cohesive devices and then compared them using Halliday and Hassan (1976) theory on cohesion to select the devices. It also used Chesterman's (1998) theory of functional contrastive analysis to analyse the difference and similarities in both languages in the area of cohesion.

\section{References}

Ballard, K. (2001). The framework of English. Hound mills: Palgrave.

Barber, C. (1964). The story of language. London: ELBS \& Pan Books Ltd.

Carrel, P. (1982). Cohesion is not coherence. TESOL quarterly, (16) 479-488. https://doi.org/10.2307/3586466

Chesterman, A. (1998). Contrastive functional analysis. Amsterdam: John Benjamins. https://doi.org/10.1075/pbns.47

Enyi, A. \& Chitulu, M. (2015). Texture, Textuality and Political Discourse: A study of lexical cohesion in Nigeria's President Goodluck Jonathan's inaugural address, May, 2011. Advances in language and literary studies Vol. 6 (5), 76-86.

Gutwinski, W. (1976). Cohesion in literary texts: A study of some grammatical and lexical Features. The Hague: Mouton.

Halliday, K. \& Hasan, R. (1985). Language, context, and text: Aspects of language in a socialsemiotic perspective. Victoria: Deakin university press.

Halliday, M. \& Hassan, R. (1976). Cohesion in English. London: Longman.

Idegbekwe, D. (2014). Lexical and grammatical cohesion in Barack Obama's speeches. Unpublished master's thesis. English studies department, university of Port Harcourt.

Jakobson, R. (1980). Concluding statement: Linguistics and poetics. Sebok. Cambridge: MIT press.

Kadiri, C., Otagburuagu, E., \& Ibrahim, A. (2015). 'Cohesion elements and interlanguage in the written composition of English as a second language university students in Nigeria.' International Journal of English and Literature (IJEL), 5(4), 35-42.

Lado, R (1957). Linguistics across cultures: Applied linguistics for language teachers. Ann Arbor: university of Michigan press.

Louwerse, M. (2004). Variation in language and cohesion across written and spoken register. Pennsylvania: the Pennsylvania state university press.

Morgan, G (2000). Discourse cohesion in sign and speech. International journal of bilingualism, (4), 279-302. https://doi.org/10.1177/13670069000040030101

Okoh, N. (2006). The challenges of Englishes in Nigeria. Port Harcourt: Pearl publishers.

Olateju, M. (2006). Cohesion in ESL classroom written texts. Nordic journal of African studies, 15(3), 314-331.

Onyeche, J. (2002). The Ika community: a sociolinguistic description. Africa and Asia, 2, 42-53.

Pyles, T. (1964). The origins and development of the English language. London: Harcourt Brace.

Querol, M. (2008). 'Substitution as a device of grammatical cohesion in English narrative and the Spanish translation.' Jornades de foment de la investigacio, 1-10.

Shen, Y. (2008). 'Characteristics of Reference Cohesion in Writing by Chinese non-English Majors.' International Cultural Studies 14, 197-210.

Traugott, E. \& Pratt, M. (1980). Linguistics for students of literature. New York: Harcourt Brace Jovanovich.

Westermann, D. and Bryan, M. (1970). The languages of West Africa. London: Dawson of Pall Mall.

Widdowson, C. (1978). Teaching language as communication. Oxford: Oxford University Press.

Yeh, C. (2004). The relationship of cohesion and coherence: a contrastive study of English and Chinese. Journal of research in reading, 2(14), 146-163. 